\title{
Accommodating Different Learning Styles in the Teaching of Economics: with Emphasis on Fleming and Mills's Sensory-based Learning Style Typology
}

\author{
Hongxiang Zhang \\ Correspondence: Hongxiang Zhang, The American University, USA. \\ Received: August 31, 2016 \\ Accepted: September 27, 2016 \\ Available online: October 12, 2016 \\ doi:10.11114/aef.v4i1.1921 \\ URL: http://dx.doi.org/10.11114/aef.v4i1.1921
}

\begin{abstract}
:
Students prefer to learn in different ways. These learning preferences are commonly known as learning styles. This variety in learning styles among students suggests that instructors should teach their course materials in different ways to cater to different learning styles. In addition, according to (Nilson 2010), when our society is concerned with fairness and equality, teaching to different styles is a main facet of equity. This paper focuses on Fleming and Mill's VARK model (1992) to describe students' different learning styles and explain why and in what ways economics instructors can accommodate different learning styles in their teaching. More specifically, the present paper aims to examine different learning styles and introduce teaching tools for accommodating different learning styles in the context of teaching economics. In addition to identifying learning-style-specific teaching instruments for the teaching of economics, the paper provides some prominent examples of each in the literature of economic education. Finally, considering recent advancements and availability of various technologies, existing evidence, general growing consensus on the issue, and many other reasons mentioned throughout the paper, it is argued and suggested that it makes more sense to take a multimodal approach to the teaching of economics.
\end{abstract}

Keywords: teaching of economics, learning styles, teaching modes, teaching tools, multimodal teaching, pedagogy

JEL Classification: A22, A23

\section{Introduction}

Individuals in general and students in particular prefer to learn in different ways. Some prefer to learn by reading and writing about a topic, others by doing hands-on activities. Some favor learning by listening to a lecture, others by watching videos and demonstrations. "All of these preferences key into the different ways people learn most easily, commonly known as learning or processing styles" (Nilson, 2010). By definition, a learning style is "the way in which a student begins to concentrate on, process and retain new and difficult information" (Hedges, 2008). The variety in learning styles among students suggests that instructors should teach their material in different ways to cater to different learning styles. In addition to the mentioned reason, Nilson (2010) argues that "particularly now, when our society is concerned with fairness and equality for those of different genders, races, ethnicities, and abilities, teaching to different styles is a major facet of equity."

According to Nilson (2010), "over the past few decades, the idea of learning styles has spawned a cottage industry. Hall and Mosley (2005) identify seventy-one different leaning-style instruments, most of which have no academic currency. [...] They identify individual differences in information processing, orientations to learning, perceived locus of control, types of intelligence, hemispheric dominance, etc." (Hall and Mosley, 2005; Sarasin, 1998). One of the learning-style models that is widely known (primarily because some K-12 leaders endorsed it) is Gardner's (1993) multiple intelligences, of which there are eight: verbal linguistic, logical-mathematical, musical, spatial, bodily-kinesthetic, interpersonal, intrapersonal, and naturalist. However, in this paper, this typology is not used since teaching to many of the intelligences is impractical and also because this typology has no empirical foundation (Morris, 2008). Instead, this paper focuses on another model called Fleming and Mill's VARK model (1992) ${ }^{1}$ which is easier to apply, more

\footnotetext{
1 You can take the VARK inventory free of charge at www.vark-learn.com/english/page.asp? $\mathrm{p}=$ questionnaire, which is a section of the extensive VARK website.
} 
popular in higher education, and more relevant to college students. ${ }^{2}$

All economics instructors undergo strict training in economic theory; however, they rarely and barely receive training in the principles of education. As a result, many economics instructors may not be taking advantage of all of existing teaching resources efficiently, and consequently, may not be providing students with an optimal education (Terregrossa and Englander, 2009; Bartlett and King, 1990).

Economics courses are taught primarily using traditional formats such as lectures and discussions along with the presentation of visual instruments such as graphs and charts. Although students with certain learning styles can best benefit from these conventional formats of teaching economics, it might not appeal to others who may find it difficult to understand and consequently become disappointed. Furthermore, there are some economic concepts and courses that are especially difficult to teach solely by the traditional and conventional teaching tools in economics. For these economics-specific reasons as well as the general reasons mentioned earlier, it would be very helpful to employ more diverse and more teaching modes, formats and tools in the teaching of economics.

The present paper aims to investigate different learning styles and examine corresponding general teaching instruments suitable for each of the learning styles. Additionally, the paper takes a further step forward and introduces teaching tools for accommodating different learning styles in the context of teaching economics. To this end, the paper utilizes Fleming and Mills's Sensory-Based Learning Style Typology and finally, by considering common sense, existing evidence and general growing consensus on the issue, suggests why and how one should take a multimodal approach to teaching economics.

More specifically, the present paper makes five contributions in total. First of all, it carries on a brief review on the education literature on learning styles. Secondly, it concisely reviews traditional, conventional, and newly proposed teaching instruments in economics. Thirdly, it links the teaching instruments and strategies to learning styles, and puts the subject matter in the context of economics. Additionally, it proposes and justifies a better combined approach, i.e. a multimodal approach to the teaching of economics. Finally, it gives examples of each of the teaching modes, introduces three approaches to making teaching multimodal, and provides some examples on how to mix up a set of modes and explains which teaching instruments are essentially multimodal. In short, the present paper is an attempt to identify teaching instruments specific to learning styles for the teaching of economics, and to provide some prominent examples of applying each instrument in the literature of economic education in the hope of increasing awareness of the need and suggesting ways for differentiated teaching practices and learning experiences that cater for a variety of intelligences in the context of teaching economics.

The paper proceeds as follows. Section 2 describes and explains Fleming and Mills's (1992) VARK model in some detail. Section 3 provides the main discussion, in which a toolkit for selecting preferred teaching tools corresponding to learning styles is proposed. Section 4 explains why a multimodal approach to teaching should be taken, and also discusses how one can make teaching multimodal. Finally, section 5 draws a conclusion on the whole discussion.

\section{Fleming and Mills's Sensory-based Learning Style Typology}

Fleming and Mills (1992) proposed a learning-styles framework that applies a descriptive classification appellation. In their classification, the terminology points to the preferred physical sense involved in the process of learning, as indicated in the four categories of read-write, aural (aka auditory), visual, and kinesthetic (aka tactile). Forming an acronym from the initial letter of each type, Fleming and Mills call their typology "VARK." Their model presumes that individuals rely on more than one style, although one type might be dominant for a certain learner. According to Nilson (2010), As Fleming \& Baume (2006) report, Svinicki endorses the use of this model by saying that "Its strength lies in its educational value for helping people think about their learning in multiple ways and giving them options they might not have considered . . . . Everyone who uses the VARK loves it, and that's a great thing to be able to say. So it is obviously striking a chord with almost everyone who uses it." In what follows, the characteristics of each type will be explained in brief.

\subsection{Visual Learners}

Students with a primarily visual learning style tend to rely on their sight to take in and process information, and learn best from presentation of materials using diagrams, graphs, and charts. As Nilson (2010) puts it, "consistent with their visual nature, these individuals organize knowledge in terms of spatial interrelationships among ideas and store it graphically as static or animated snapshots, flowcharts, pictures, or diagrams."

\footnotetext{
2 There are some other models of learning styles that could be used for this purpose, two of which are Kolb's model of the learning cycle and learning styles (1984) and Felder and Silverman's index of learning styles (1988). However, for the reasons mentioned above, the present paper uses the Fleming and Mills's Sensory-Based Learning Style Typology.
} 
Some visual learners even have photographic memories. Aiming at the provision of aids for visual learners, instructors need to illustrate the implicit connection and relation between conceptions utilizing explicit visual forms. This kind of learners could more easily and comprehensively grasp the essence of knowledge, if the links between or even the whole system were displayed to them more photographically and concisely.

Examples of the visual forms that students with this learning style tend to use include diagrams, illustrations, pictures, flowcharts, graphs, histograms, animations, concept and mind maps, graphic models, graphic organizers, and graphic metaphors. ${ }^{3}$ With the advancement of technology, visual teaching tools, such as the chalkboard, overhead transparencies, presentation slides, handouts, instructional computer software, and videotapes, are nowadays readily and easily available.

\subsection{Auditory Learners}

Students with an auditory learning style achieve high quality output through the "heard" information. This kind of students benefits from classical teaching methods including lecture, peer tutoring, in-class discussion, and personal/group presentation, also some emerging pedagogical tools such as podcasts and music. Moreover, other than auditory information received from outside, they can make even more profit from themselves by various forms of audio recordings.

\subsection{Read/Write Learners}

Students with a read/write learning style are very skilled at dealing with words. They can readily comprehend the structure of an article, paper or textbook, distill the gist from all relevant parts, and comb the logical relationship among factors. Exploiting their character of abstract thinking, this kind of learners performs better in the traditional reading and writing framework of class, compare to students with other learning styles, which require more learning materials other than just textbook and homework.

\subsection{Kinesthetic Learners}

Students with a kinesthetic learning style collect knowledge mainly from reality, particularly from something they can touch and/or operate. They are physically astute; therefore, they prefer to be more involved in active participation. They learn better from manual experience, problem-solving based on examples, practice and conducting experiment/simulation using tools and/or computers. The teaching strategies towards this kind of learners include case studies, field trips, body games, laboratory activities, modeling and artistic creations. ${ }^{4}$

Kinesthetic learning style differs from others since it's a more comprehensive method which combines the features of other learning styles. An instructor could utilize visual, aural and read/write manners to present information from kinesthetic experience. Among all these learning styles, visual learners share several same techniques as kinesthetic ones, as both types rely on graphically exhibition of learning materials. Unfortunately, this kind of graphical learners are often left behind in traditional class settings, since they demand supplementary learning resources to support their unique learning process. Therefore, instructors have obligations to develop and offer more teaching techniques towards these students. Figure 1 depicts and summarizes the VARK learning styles in a visual manner.

\footnotetext{
3 As Nilson (2009) explains and exemplifies, a graphic metaphor is "a drawing of an analogical relationship, such as a sketch of a building to represent a Marxian view of society, with the basement as the 'substructure' and the floors above as the 'superstructure'."

${ }^{4}$ Nilson (2009) provides great explanations of these teaching methods.
} 


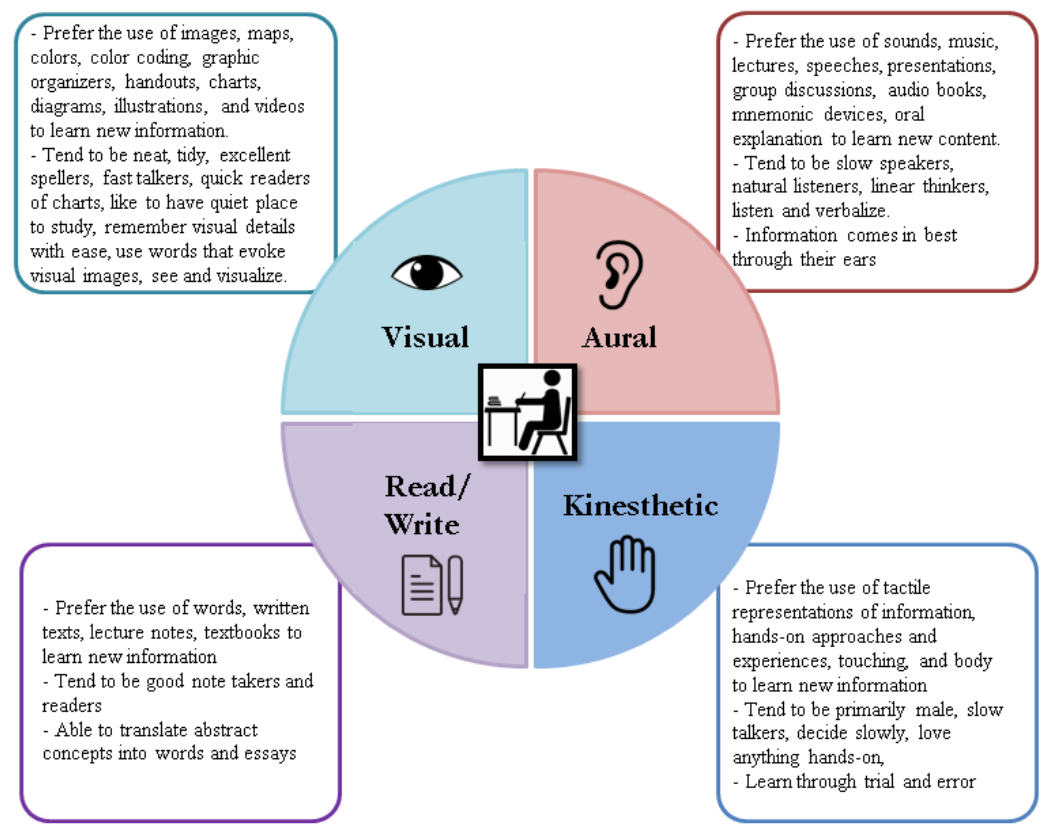

Figure 1. An Illustration of the VARK Learning Styles

Source: Author's Design

In the next section, different teaching tools that can serve the VARK in the context of economics classroom will be discussed.

\section{Main Discussion: Economics Teaching Tools Corresponding to Learning Styles}

As discussed earlier, Fleming (1995) suggests that students with a visual preference learn best from visual presentation of materials such as graphs, diagrams, and the like; aural learners prefer to take in information through listening to music, lectures, audio books and files, and other similar mediums; read/write learners prefer to receive information through writing and reading from printed words such as lecture notes, textbooks, and so on; and kinesthetic learners often gain better understanding of materials through concrete examples, applications, experience, and trial and error.

In addition, as Leung et al. (2014) report, research suggests that performance of students can vary in relation to their thinking and learning styles. For instance, Zhang (2004) has found that students with certain thinking styles preferred certain teaching styles, which can influence their academic performances consequently. Another study conducted by Charkins, et al. (1985) found that "the larger the gap between an instructor's teaching style and a student's learning style, the worse the student's performance in the introductory economics course." In other words, existing evidence shows that inconsistency between the teaching modes used to teach course materials and a student's learning style can negatively affect the student's performance. Brokaw and Merz (2000) found that, in principles of microeconomics courses, the students whose learning styles accorded with their instructors' "chalk and talk" style had significantly higher grades (by half a letter grade) than those students whose learning styles did not accord.

Frank (2007) emphasizes the importance of the manner by which economic content is taught. According to him, the form in which ideas are conveyed is very important. Reich (2000) states, "We're creating a one-size-fits-all system that needlessly brands many young people as failures, when they might thrive if offered a different education." One implication in Reich's statement could be the idea that the more the teaching styles that an instructor uses is close to her students' preferred learning styles, rather than a homogeneous fashion, the more easily students could thrive academically and thus become better equipped professionally.

Economics courses are taught mostly using traditional formats such as lectures along with the presentation of visual instruments such as graphs and charts, which is widely known as the "chalk and talk" method", and thus, differences in students' learning styles are ignored. This way, the potential improvement in student performance which is achievable from matching instructors' teaching methods with students' learning styles is lost. As Terregrossa and Englander (2009)

\footnotetext{
5 The 'chalk-and-talk' teaching method is a teaching method that employs lectures along with some supporting mediums such as notes, slides, equations and diagrams written up on the chalkboard.
} 
put it, "it is ironic that the practitioners of the discipline devoted to the study of efficiency principles [i.e. economics] are implicitly accused of being inefficient in their approach to teaching that discipline." As they mention, "the optimal method of teaching is the method that most closely matches students' learning styles." Moreover, there are some economic concepts and courses that are especially difficult to teach solely by conventional and traditional teaching instruments such as lecture and discussion.

If we appreciate that different students learn in different ways, and that research suggests students' performance level can be inversely dependent on the gap between instructors' teaching styles and students' learning styles, and that traditional formats of teaching economics do not appeal to all students, and that some economic concepts are difficult to be taught by conventional teaching tools, then a reasonable approach to teaching economics would be accommodating different learning styles in our teaching by using different teaching tools, modes, and formats. However, the literature has thus far not introduced a toolkit from which economics instructors can readily choose their needed teaching modes and tools and somehow account for students with different learning styles. In fact, the primary purpose of this section is to help economics instructors take such an approach to their teaching of economics. This task is to be undertaken in the form of a table, in which characteristics of each of the learning styles, preferred teaching mediums of each, and suitable tools for the teaching of economics along with some examples of best practices corresponding to each of the learning styles are presented. Table 1 provides economics instructors with some basic ideas on how to accommodate various learning styles in the classroom and a few of the paragraphs following it will elaborate the related matters to some extent.

Table 1. A Proposed Toolkit for Selecting Your Preferred Teaching Mediums and Tools According to Students' Learning Styles

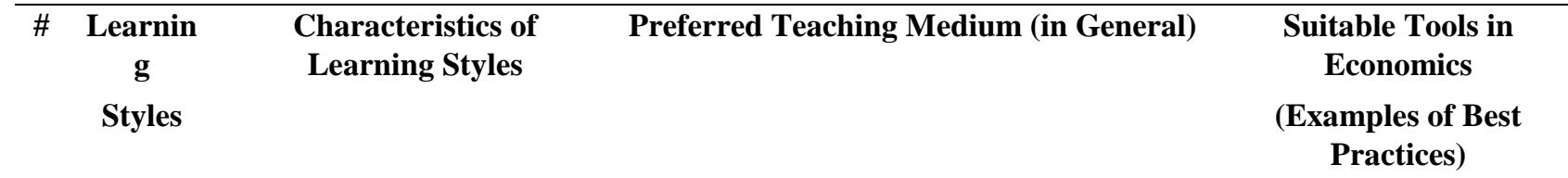

\begin{aligned} \hline Visual/ & $\begin{array}{l}\text { - Prefer the use of images, } \\ \text { maps, colors, color coding, } \\ \text { graphic organizers, } \\ \text { handouts, charts, diagrams, } \\ \text { illustrations, structure, } \\ \text { links, and videos. }\end{array}\end{aligned}$

- Tend to be neat, tidy, excellent spellers, fast talkers, quick readers of charts, like to have quiet place to study, remember visual details with ease, use words that evoke visual images, see and visualize.

- Organize knowledge in terms of spatial interrelationships among ideas and store it graphically as static or animated snapshots, flowcharts, pictures, or diagrams.

2 Aural/ - Prefer the use of sounds, Auditory music, lectures, speeches, / presentations, group Musical discussions, audio books, mnemonic devices, and oral explanation to learn
Static or animated snapshots, flowcharts, pictures, 2D and 3D diagrams, plots, charts, graphs, visual aids, two-dimensional spatial relationships, etc.

Visual teaching tools are readily available: the chalkboard, presentation slides, overhead transparencies, and handouts. Some instructional computer software and videotapes also feature outstanding graphical depictions of relationships. Using only the least expensive options, you can diagram the relationships among major points in your lectures and the readings.

You can add visual components like graphs and histograms to the day's lesson. You can chart complex, logical relationships among overlapping concepts with circle (Venn) diagrams. You can draw flowcharts of multistage assignments, such as the essay-writing process, problem-solving strategies, and laboratory procedures. You can even flow-chart your student learning outcomes from the beginning to the end of the term (see chapter two of Nilson 2010).

Audio files, different types of verbal presentation (e.g., a discussion, lecture, debate), narratives, music, interactive lectures, directed discussion, panel discussion, and mnemonic devices.
The Graphic Syllabus (Nilson 2010), the outcome map (Nilson, 2007), visual "big pictures" (Moosavian, 2016c, 2016d, 2016e) and Naumenko and Moosavian (2016), the Interactive Graphic Syllabus (Moosavian, 2016f) concept maps and mind maps, graphic models and organizers, summary tables, graphic metaphors, YouTube instructional videos (e.g., Khan Academy and the like), interactive visualizations, using arts (paintings, drawings, and engravings) to teach economics (Watts \& Christopher, 2012), etc.

Rockonomix (Holder et al., 2015), Pod learning (Moryl, 2015), podcasts as a tool for teaching economics (Moryl, 2015), uses of music in 
new content.

- Tend to be slow speakers, natural listeners, linear thinkers, listen and verbalize.

- Information comes in best through their ears.

3 Read/ - Prefer the use of words, Write written texts, lecture notes, textbooks to learn new information.

- Tend to be good note takers and readers.

- Able to translate abstract concepts into words and essays.

4 Kinesthe - Prefer the use of tactile tic/Tactil representations of e/ information, hands-on Physical approaches and experiences, touching, and body to learn new information.

- Tend to be primarily male, slow talkers, decide slowly, and love anything hands-on.

- Learn through doing, experiencing, and trial and error, and use active involvement as the primary learning mode

teaching the history of economic thought (Van Horn \& Van Horn, 2013), demand and supply rap based on Mankiw's 10 principles of economics (www.educationalrap.co m/song/demand-supply/) , etc.

Words, reading, and other types of verbal presentation.

They store information as organized sets of symbols, such as outlines, equations, diagrams, and typologies. As you can imagine, these learners do well in the traditional educational setting. The reading and lecture format so common in classrooms is tailor-made for them, and they need no special instructional considerations.

Building, highlighting, compiling, marking off, underscoring, computer hardware and software, clickers, Poll Everywhere (www.polleverywher.com), smartphones, practical applications, lab sessions, activities, classroom experiments, classroom games, physical models and analogies, replications, problem-based teaching, project-based teaching, role playing, etc.

(Traditional and conventional approaches to teaching economics have not been friendly to students with a kinesthetic preferences. However, recently, the situation has to some extent improved for them.)
Conventional and traditional teaching tools are appropriate formats for these learners, such as economics-related written texts, lecture notes, textbooks, and equations. Also, encourage students to write their own data interpretation or extended response questions, etc.

Simulations, case methods, problem-based learning,

experiential methods, software programs,

experiments in the classroom (e.g. see Holt (1999) and Holt and Laury (1997)), games in the classroom (see Journal of Economics Education), 3D-printed prototypes of utility and production functions

(Moosavian, 2016b)

research replications using the same datasets, etc.

To provide a few additional notable examples of teaching tools suitable for visual economics learners and also to further elaborate some of the examples cited in table 1, it is worthwhile to mention that Moosavian (2016c) introduces the notion of visual "big pictures" 6 in the teaching of economics to show how to effectively communicate the structure of a course of study. ${ }^{7}$ To mention a few additional examples, Méndez-Carbajo (2015) discusses a pedagogical strategy based on data visualization and analysis using online FRED database in the teaching of intermediate macroeconomics

\footnotetext{
${ }^{6}$. Visual "big pictures" can be categorized as a sub-category of what is known as concept or mind maps in the education literature (which are spatial arrangements of concepts or stages linked by lines or arrows). However, it is crucial to note that the main aim of a visual "big picture" is to communicate the whole "structure" of a subject matter at least or a course of study ideally.

7. To see three excellent examples of a visual "big picture" in the context of teaching economics, you can see Moosavian (2016) which provides an example of a visual "big picture" for the course of intermediate macroeconomics. Also, Naumenko and Moosavian (2016) provide the visual "big picture" of production theory in advanced microeconomics and shows how one can clarify theoretical intricacies through the use of conceptual visualization. In addition, Moosavian (2016) introduces and Moosavian (2016) elaborates a comprehensive visual "big picture" for consumer theory which has been called "wheel of duality" in consumer theory.
} 
and financial economics. Additionally, Watts and Christopher (2012) show how to effectively use art such as paintings, drawings, and engravings in the teaching of economics. Moosavian (2016f) also introduces the Interactive Graphic syllabus and puts the idea into practice for the case of intermediate macroeconomics.

To see a few teaching tools suitable for aural learners, you might want to see the idea of Rockonomix by Holder et al. (2015) which somehow makes use of the auditory sense to teach economics to those who have a passion for music. Furthermore, Moryl (2015) puts forth the idea of pod learning in which student groups create podcasts as a class project to achieve economics learning goals. That is, she uses podcasts as a teaching instrument for the teaching of economics. As another example, Horn and Horn (2013) in a paper entitled "What Would Adam Smith Have on His iPod?" shows how one can make use of music as an active learning technique in teaching the history of economic thought.

In order to have a few more options for teaching tools suitable for read/write learners, economics instructors can have their students restate, paraphrase, summarize, and annotate economic texts and journals. Incidentally, they can assign one-sentence summaries, one-minute papers, electronic posts, and/or give mock tests. ${ }^{8}$ These techniques seem to be appropriate for familiarizing students with economics literature and also for teaching the history of economic thought. Crowe and Youga (1986) write on how to use writing as a tool for learning economics. Hoyt and McGoldrick (2012) in a book entitled "International handbook on teaching and learning economics" which is a selection of notable papers in the area of economics education have included several articles that elaborate how to use writing as a teaching tool for economics.

There are many additional teaching tools and techniques that can be applied for teaching kinesthetic economics learners. These tools and techniques include in-class experiments ${ }^{9}$, in-class games for teaching game-theoretic and auction-related concepts $^{10}$, on-line games (including free games, commercial games, and your own games) ${ }^{11}$, simulations $^{12}$ (e.g. using Microsoft Excel) ${ }^{13}$, physical models, analogies, and prototypes (an excellent example of these tools which has been used in teaching economics has been introduced by Moosavian (2016b) $)^{14}$, etc. Some of economic concepts and courses are more applicable to be taught using the kinesthetic mode. Examples are econometric and statistical analyses, applied economic analysis, game theory and auctions, mathematics for economists, and geometry of utility and production functions.

It is important to note that in the education literature, there have been put forth other types of leaning style typologies. Three of the more common ones are: Gardner's, which is often used in K-12; Kolb, which is basically designed to inform training in private industry and is essentially a business tool; and Felder and Silverman, which is initially introduced for engineering students, but applies to learners across the disciplines. Gardner divides learning styles into eight types including verbal linguistic, logical-mathematical, musical, spatial, bodily-kinesthetic, interpersonal, intrapersonal, and naturalist. Kolb classifies learning styles into accommodators, divergers, convergers, and assimilators. ${ }^{15}$ Felder and Silverman divide learning styles into active vs. reflective learners; verbal vs. visual; intuitive vs. sensing; and sequential vs. global. ${ }^{16}$ As it should be obvious, there is some overlap and parallel among some of the

\footnotetext{
8. Many of the teaching tools, methods, and techniques brought up here might be unfamiliar to you. In order to gain further information on those, you might want to study some of the education books. For this purpose, Nilson (2010) is a good one to start with.

9. For instance, Bergstrom et al. (2013) describe a classroom experiment which they have designed to present the idea of two-sided matching, the concept of a stable assignment, and the Gale-Shapley deferred-acceptance mechanism. Additional popular examples could be in-class experiments to give a sense of the law of diminishing returns, price discrimination, and public goods determination.

${ }^{10}$. Journal of Economic Education is full of fine examples of classroom games and experiments.

${ }^{11}$. To see a list of such games you can see Smith (n.d.). A notable example is the FED online game which teaches the role of Federal Reserve in form of a game.

${ }^{12}$. It is important to note that simulation games have many advantages, such as making economics "real", and being an experiential learning tool which can be used either to introduce or consolidate materials or both.

13. As an instance, Gilbert and Oladi (2011) provide some Excel models as an online resource which can be used in the teaching of the course of International Trade Theory and Policy.

14. Moosavian (2016) has 3D-printed prototypes of common utility and production functions in order to teach geometric, mathematical, and theoretical characteristics of these functions. By using these tools, he shows how an economics instructor can introduce three major types of utility and production functions, two polar cases, namely perfect substitutes and perfect complements, and an intermediate one, i.e. Cobb-Douglas utility and production function. These models also clarify the concept of isoquants, indifference map, and the existence of infinite number of indifference curves, the convexity of indifference curves, the (quasi-)concavity of utility and production function the concepts of budget constraint, budget line, and budget set, the interpretation of the concept of constrained maximization in a geometric fashion.

${ }^{15}$. Kolb classifies learning styles into accommodators, who rely heavily on concrete experience and active experimentation; divergers, who use concrete experience as well as reflective observation; convergers, who rely primarily on their skills of abstract conceptualization and active experimentation in their learning; assimilators, who combine abstract conceptualization and reflective observation into a style that excels at organization and synthesis (Nilson, 2010).

${ }^{16}$. Notice that Felder and Silverman's model suggests four independent aspects on which learners differ, not exactly types of learners.
} 
learning styles of different models. As a result, many of the tools and modes introduced in table 1 on the basis of Fleming and Mills's Sensory-Based Learning Style Typology can be applied to accommodate many of the other learning styles models posited by other scholars. ${ }^{17}$

As a summary table, table 1 provided economics instructors with some ideas on how to cater to different learning styles in the classroom. In the next section, a comprehensive approach that makes more sense to be taken to the teaching of economics is proposed.

\section{Teaching Economics Using Multimodal Approaches}

Regardless of an instructor's own favorite learning styles, it is important to keep in mind that students in the class are not of one learning style or another. Most likely, they tend to use multiple learning modes and strategies. In general, all students learn best and most when they are provided with multiple-sense, multiple-method instruction, which is known as multimodal teaching. According to Nilson (2010), "people learn best when they receive the new materials multiple times and in different ways." In other words, individuals learn best when they employ several senses and modes that apply various parts of their brain (Kress, Jewitt, Ogborn, and Charalampos, 2006; Vekiri, 2002).

In order to take a multimodal approach to the teaching of economics, economics instructors can either use the tools that are essentially multimodal, or they can teach a single concept multiple times through multiple modes that employ different intelligences, or they can teach each concept using the modes that best fit that particular concept. An example of the first method could be when an instructor takes advantage of a visual "big picture" to communicate the structure of a course of study, which helps not only visual learners, but also global, sequential, and potentially read/write learners. An example of the second method could be the case in which the characteristics of utility functions are explained once through text, another time through mathematical equations, and one additional time through visuals and 3D-printed prototypes of the functions, as Moosavian (2016b) proposed. That way, the instructor has indeed employed visual, $\mathrm{read} / \mathrm{write}$, and kinesthetic teaching modes. Thereby, different students who are of different types and prefer different learning styles can benefit from at least one or more of the modes and better and more learn about utility and production functions. The third way to put the notion of multimodal teaching into action is to teach each concept through the mode that seems to be the best fit and easiest for that particular concept. For instance, in order to communicate the structure of a course, it seems that visualization techniques such as concept and mind maps or visual "big pictures" are the best fit, while to teach details and specifics of a subject matter aural and read/write modes seem to be better fits. As another example, for teaching game theoretic concepts, visual modes such as strategy profile, and trees seem to be a suitable fit, while for teaching the history of economic thought read/write mode seem to be a good fit.

Three additional examples of essentially multimodal teaching tools are the Graphic Syllabus (Nilson, 2010 and 2009), the Interactive Syllabus (Richards, 2003), and the Interactive Graphic Syllabus (Moosavian, 2016f). In supporting the idea of the Graphic Syllabus, Nilson (2009) explains the pedagogical power of graphics by referring to dual-coding theory and the visual argument theory. She also gives some evidence on the power and potential of graphics in increasing the efficiency of learning and retention, as well as reaching visual, global and intuitive learning styles. However, further elaboration of these pieces of evidence is beyond the scope of the present paper. According to Richards (2003), the main idea behind the Interactive Syllabus is to "populate the syllabus with rich, robust media that will appeal to students' different learning styles." The media can be of different forms such as texts, full length texts of online books, publishers' online course materials, images, audio, and video, which cater to learners with different learning preferences.

According to Moosavian (2016f), applying a well-designed Interactive Graphic syllabus can bring us many advantages including appealing to many of learning styles and engaging students with different learning styles. The resources collected from the Internet must not only be appropriate in terms of subjects, but also target various learning styles. For example, as he mentions, "global learners will usually benefit from the Interactive Graphic Syllabus by looking at the comprehensiveness of the structure which is provided by the visual "big picture" of the course or ideally the field. Sequential learners will routinely benefit from the sequential and possibly logical orders of the components included in the visual "big picture". Visual learners will commonly benefit from pictures, diagrams ${ }^{18}$, maps, videos, and animations. Auditory learners will appreciate audio files. Kinesthetic learners will take advantage of materials with controls that allow them to regulate the way in which they interact with materials." As a result, a correctly-designed interactive

\footnotetext{
${ }^{17}$. In addition to the mentioned models, there are other less-popular models that divide learners in terms of their learning styles into other categories. However, for the sake of space economy and compactness of the paper, I fail to discuss those models.

18. In order to find more information about how to design helpful diagrams with desirable features from a cognitive point of view, you can read the article entitled "When do diagrams enhance learning? A framework for designing relevant representations," written by Davenport et al. (2008).
} 
graphic syllabus should serve and appeal to all of the above-mentioned learning styles in its use of materials. ${ }^{19}$

All in all, considering the facts that students learn best and most and more effectively when they are taught in a multimodal manner, and that multimodal teaching is more engaging and as a result more appealing to students, and that it is more in line with equity principles, and finally that it is more flexible for teaching different courses of different natures, it can be said that multimodal teaching is a very effective approach to take to the teaching of economics. In addition, in the presence of the recent advancement of technology, which in turn presents new opportunities in schools and at home, taking a multimodal approach to the teaching of economics is an easier task to be carried out than ever before. Also, there is adequate evidence (e.g. Leung et al., 2014; Charkins, et al., 1985; Zhang, 2004; and Brokaw and Merz , 2000) and a growing general consensus (e.g. Reich, 2000; Frank, 2007; and Terregrossa and Englander, 2009) on the effectiveness of multimodal teaching. Additionally, common sense suggests that it makes more sense to use all the senses and intelligences gifted which provide students with a handful of input channel formats rather than one or two.

As Nilson (2010) explains, teaching to multiple styles and modes not only help students with various learning styles learn more easily, but it can also help instructors somehow revitalize their lesson plans and classroom presentations that have become routine through repetition. She then goes on to say that "adding visual and kinesthetic components, inquiry-guided activities, group work, and experiential learning may take some time and effort, but the change can avert burnout." She suggests that to maximize all of their students' learning and their own professional fulfillment, instructors should try to employ a wide, rich variety of teaching tools and techniques in their courses. Additionally, they ought to acquaint their students with the wide range of learning and studying strategies." In Nilson's opinion, bringing this variety and flexibility into teaching is the real virtue of all the learning style models.

\section{Conclusion}

The present paper investigates different learning styles and examines their corresponding teaching tools for accommodating learners with different learning preferences in the context of teaching economics. It also provides some notable examples of employing each tool in the literature of economic education in the hope of increasing awareness of the need and suggesting ways for differentiated teaching practices and learning experiences that cater for a variety of intelligences. To achieve this goal, Fleming and Mills's Sensory-Based Learning Style Typology is utilized. The paper introduces a toolkit from which economics instructors can readily choose their needed teaching modes and tools and somehow account for students with different learning styles. Table 1 provides economics instructors with some basic ideas on how to accommodate various learning styles in the classroom.

Since students prefer to learn in different ways, it is suggested that instructors should teach their course materials in different ways to cater to different learning styles. In addition, teaching to different styles can be regarded as a main dimension of equity. Due to lack of receipt of sufficient training in the principles of education, many economics instructors may not be employing existing teaching resources efficiently and thus not be providing students with an optimal education. Economics courses are taught primarily using traditional formats such as lectures along with the presentation of visual instruments such as graphs and charts. This way of teaching economics might not appeal to those who may find it difficult to understand and consequently become disappointed. Furthermore, there are some economic concepts and courses that are especially difficult to teach solely by the traditional and conventional teaching tools in economics.

Fleming (1995) suggests that students possess various learning preferences. Leung et al. (2014) report that performance of students can vary in relation to their thinking and learning styles. Zhang (2004) finds that students with certain thinking styles preferred certain teaching styles. Charkins, et al. (1985) find that inconsistency between the teaching modes used to teach course materials and a student's learning style can negatively affect the student's performance. Frank (2007) emphasizes that the form in which ideas are conveyed is very important. Reich (2000) implicitely suggests that the closer the teaching styles that an instructor uses is to her students' preferred learning styles, the more easily students could thrive academically and thus become better equipped professionally.

Throughout the paper, it is argued that, for the following reasons, a reasonable approach to teaching economics would be accommodating different learning styles by using different teaching tools, modes, and formats, which is a way of teaching known as multimodal teaching in the literature of education. The first reason is simply the fact that different students prefer to learn in different ways. Second, research suggests that students' performance level can be inversely dependent on the gap between instructors' teaching styles and students' learning styles. Third, traditional formats of teaching economics do not appeal to all students. Fourth, some economic concepts are difficult to be taught by conventional teaching tools. Fifth, students learn best and most and more effectively when they are taught in a multimodal manner. Sixth, multimodal teaching is more engaging and more appealing to students. Seventh, it is more flexible for teaching different courses of different natures. Eighth, in the presence of the recent advancement of

${ }^{19}$. Needless to say, besides the advantages mentioned here, the Interactive Graphic Syllabus essentially inherits and naturally nests those of both the Interactive Syllabus as well as the Graphic Syllabus. 
technology, taking a multimodal approach to the teaching of economics is an easier task to be undertaken than ever before. Ninth, there is significant evidence (e.g., Leung et al., 2014; Zhang, 2004; and Brokaw and Merz, 2000; and Charkins, et al., 1985) and a growing general consensus (e.g., Terregrossa and Englander, 2009; Reich, 2000; and Fand, 2007) on the effectiveness of multimodal teaching. Tenth, common sense suggests that it makes more sense to use all the senses and intelligences gifted which provide students with a handful of input formats rather than one or two. For these reasons, it can be said that multimodal teaching is a very effective approach to take to the teaching of economics.

In order to take a multimodal approach to the teaching of economics, economics instructors can either use the tools that are essentially multimodal (e.g visual "big pictures" as argued throughout the paper), or they can teach a single concept multiple times through multiple modes that employ different intelligences, or they can teach each concept using the modes that best fit that particular concept. As Nilson (2010) explains, teaching to multiple styles and modes not only help students with various learning styles learn more easily, but it can also help instructors somehow revitalize their lesson plans and classroom presentations that have become routine through repetition.

\section{References}

Bergstrom, C. T., Bergstrom, T. C., \& Garratt, R. J. (2013). Choosing Partners: A Classroom Experiment. The Journal of Economic Education, 44(1), 47-57. http://dx.doi.org/10.1080/00220485.2013.740391

Cassidy, S. (2004). Learning styles: An overview of theories, models, and measures. Educational psychology, 24(4), 419-444. http://dx.doi.org/10.1080/0144341042000228834

Charkins, R. J., O'Toole, D. M., \& Wetzel, J. N. (1985). Linking teacher and student learning styles with student achievement and attitudes. The Journal of Economic Education, 16(2), 111-120. http://dx.doi.org/10.1080/00220485.1985.10845106

Crowe, D., \& Youga, J. (1986). Using writing as a tool for learning economics. The Journal of Economic Education, 17(3), 218-222. http://dx.doi.org/10.1080/00220485.1986.10845169

Crowe, R. (2000). Know Your Student's Learning Style: The Missing Link in the Lecture vs. Active Learning Issue.

Davenport, J. L., Yaron, D., Klahr, D., \& Koedinger, K. (2008, June). When do diagrams enhance learning? A framework for designing relevant representations. In Proceedings of the 8th international conference on International conference for the learning sciences, International Society of the Learning Sciences, 1, 191-198.

Felder, R. M., \& Silverman, L. K. (1988). Learning and Teaching Styles in Engineering Education. Engineering Education, 78(7), 674-681.

Fleming, N. D. (1995, July). I'm different; not dumb. Modes of presentation (VARK) in the tertiary classroom. In Research and Development in Higher Education, Proceedings of the 1995 Annual Conference of the Higher Education and Research Development Society of Australasia (HERDSA), HERDSA

Fleming, N. D., \& Mills, C. (1992). Not another inventory, rather a catalyst for reflection.

Frank, R. H. (2007). The Dismal Science, Dismally Taught, Economic View, Sunday Business, New York Times, August 12: BU 4.

Gardner, H. (1993). Frames of Mind: The Theory of Multiple Intelligences, New York: Basic Books.

Gilbert, J., \& Oladi, R. (2011). Excel models for international trade theory and policy: An online resource. Journal of Economic Education1, 42(1), 95-95. http://dx.doi.org/10.1080/00220481003727472

Hall, E., \& Mosley, D. (2005). Is There a Role for Learning Styles in Personalized Education and Training?, International Journal of Lifelong Learning, 24(3), 243-255. http://dx.doi.org/10.1080/02601370500134933

Hedges, M. (2008). Learning styles and introductory economics: A matter of translation. Australasian Journal of Economics Education, 5(1), 1-16.

Hedges, M. R. (2008). Learning styles and introductory economics: A matter of translation.

Holder, K., Hoffer, A., Al-Bahrani, A., \& Lindahl, S. (2015). Rockonomix. The Journal of Economic Education, 46(4), 443-443. http://dx.doi.org/10.1080/00220485.2015.1071216

Holt, C. A. (1999). Teaching economics with classroom experiments: A symposium. Southern Economic Journal, 603-610. http://dx.doi.org/10.2307/1060819

Holt, C. A., \& Laury, S. K. (1997). Classroom games: Voluntary provision of a public good. The Journal of Economic Perspectives, 11(4), 209-215. http://dx.doi.org/10.1257/jep.11.4.209

Hoyt, G. M., \& McGoldrick, K. (Eds.). (2012). International handbook on teaching and learning economics. Edward Elgar Publishing. 
Kolb, D. A. (1984). Experiential Learning: Experience as the Source of Learning and Development. Upper Saddle River, NJ: Prentice Hall

Kress, G., Jewitt, C., Ogborn, J., \& Charalampos, T. (2006). Multimodal Teaching and Learning: The Rhetorics of the Science Classroom. London: Continuum.

Leung, A., McGregor, M., Sabiston, D., \& Vriliotis, S. (2014). VARK learning styles and student performance in principles of Micro-vs. Macro-Economics. Journal of Economics and Economic Education Research, 15(3), 113.

Méndez-Carbajo, D. (2015). Visualizing Data and the Online FRED Database. The Journal of Economic Education, 46(4), 420-429. http://dx.doi.org/10.1080/00220485.2015.1071222

Moosavian, S. A. Z. N. (2016a). A Comprehensive Visual "Wheel of Duality" in Consumer Theory. International Advances in Economic Research, 1-2. http:/dx.doi.org/ 10.1007/s11294-016-9586-8

Moosavian, S. A. Z. N. (2016b). Industrial Design at the Service of Teaching Economics: 3D-Printed Prototypes and Materialized Demonstrations of Utility and Production Functions, Manuscript in preparations.

Moosavian, S. A. Z. N. (2016c). Teaching Economics and Providing Visual "Big Pictures". Journal of Economics and Political Economy, 3(1), 119-133. http://dx.doi.org/10.1453/jepe.v3i1.631

Moosavian, S. A. Z. N. (2016d). The Visual 'Big Picture' of Intermediate Macroeconomics, International Journal of Economics and Finance, 8(9), 234-248. http://dx.doi.org/10.5539/ijef.v8n9p234

Moosavian, S. A. Z. N. (2016e). The Visual Decoding of the "Wheel of Duality" in Consumer Theory in Modern Microeconomics: An Instructional Tool Usable in Advanced Microeconomics to Turn "Pain" into "Joy". Applied Economics and Finance, 3(3), 288-304. http://dx.doi.org/10.11114/aef.v3i3.1718

Moosavian, S. A. Z. N. (2016f), Using the Interactive, Graphic Syllabus in the Teaching of Economics, Manuscript in preparation.

Moosavian, S. A. Z. N., \& Naumenko, A. (2017, January). An Atlas of Economics: Teaching Tools for Navigating the 'Big Picture', A poster presented at the 2017 Allied Social Sciences Association (ASSA) Meeting in the American Economic Association (AEA) Economic Education Poster Session, Chicago, IL, USA.

Moryl, R. L. (2015). Pod Learning: Student Groups Create Podcasts to Achieve Economics Learning Goals. Available at SSRN 2638457.

Naumenko, A., \& Zeytoon, N. M. S. A. (2016). Clarifying Theoretical Intricacies through the Use of Conceptual Visualization: Case of Production Theory in Advanced Microeconomics, Applied Economics and Finance, 3(3), 103-122. doi:10.11114/aef.v3i4.1781

Naumenko, A., \& Zeytoon, N. M. S. A. (2016, February). Clarifying Theoretical Intricacies through the Use of Conceptual Visualization: Case of Production Theory in Advanced Microeconomics, A paper presented at the 27th Annual Teaching Economics Conference - Instruction and Classroom Based Research, held by Robert Morris University \& McGraw Hill/Irwin Publishing Company, Pittsburgh, Pennsylvania, USA, 18-20 February, 2016.

Nilson, L. B. (2009). The Graphic Syllabus and the outcomes map: Communicating your course (Vol. 137). John Wiley \& Sons.

Nilson, L. B. (2010). Teaching at its best: A research-based resource for college instructors. John Wiley \& Sons.

Pashler, H., McDaniel, M., Rohrer, D., \& Bjork, R. (2008). Learning styles concepts and evidence. Psychological science in the public interest, 9(3), 105-119.

Reich, R. B. (2000). One Education Does Not Fit All. OpEd, New York Times, July 11: A25.

Richards, S. L. (2003). The Interactive Syllabus: A resource-based, constructivist approach to learning. The Technology Source.

Sarasin, L. C. (1998). Learning Styles Perspective: impact in the Classroom, Madison, WI: Atwood.

Siriopoulos, C., \& Pomonis, G. A. (2007). A Comparative Analysis of Economics Graduates' Learning Attitudes: Implications for Teaching. Available at SSRN 978520. http://dx.doi.org/10.2139/ssrn.978520

Smith, V. (n.d.). Multi-Modal Approaches to Teaching Economics. Presentation, available at: http://www.bea.asn.au/cms/files/cms_files/BEA\%20Conference\%2012\%20-\%20Handouts/D1_Vanessa_Smith_M ulti-modal\%20approaches\%20to\%20teaching\%20Economics_BEA12.ppt.

Terregrossa, R. A., \& Englander, V. (2001). Teaching college economics: Efficiency issues. Journal of Private Enterprise, 17(Fall 2001), 52-60. 
Terregrossa, R. A., Englander, F., \& Wang, Z. (2009). Why learning styles matter for student achievement in college economics. Journal for Economic Educators, 9(1), 16-31.

Van Horn, R., \& Van Horn, M. (2013). What would Adam Smith have on his iPod? Uses of music in teaching the history of economic thought. The Journal of Economic Education, 44(1), 64-73. http://dx.doi.org/10.1080/00220485.2013.744619

Vekiri, I. (2002). What is the Value of Graphical Displays in Learning? Educational Psychology Review, 14(3), 262-312. http://dx.doi.org/10.1023/A:1016064429161

Watts, M., \& Christopher, C. (2012). Using art (paintings, drawings, and engravings) to teach economics. The Journal of Economic Education, 43(4), 408-422. http://dx.doi.org/10.1080/00220485.2012.714317

Zeytoon, N. M. S. A. (2016, February). A Briefcase of 3D Utility and Production Functions: An Innovative, Pedagogical Tool to Teach Microeconomics, presented at the 27th Annual Teaching Economics Conference Instruction and Classroom Based Research, held by Robert Morris University \& McGraw Hill/Irwin Publishing Company, Pittsburgh, Pennsylvania, USA, 18-20 February, 2016.

Zeytoon, N. M. S. A. (2016, June), Employing Technology in Providing an Interactive, Visual "Big Picture" for Macroeconomics: A Major Step Forward towards the Web-Based, Interactive, and Graphic Syllabus, Paper presented at the Sixth Annual American Economic Association (AEA) Conference on Teaching and Research in Economic Education (CTREE), Atlanta, GA, USA.

Zeytoon, N. M. S. A. (2016c). Teaching Economics and Providing Visual" Big Pictures". arXiv preprint arXiv:1601.01771.

Zeytoon, N. M. S. A. (2016d). The Visual "Big Picture" of Intermediate Macroeconomics: A Pedagogical Tool to Teach Intermediate Macroeconomics. International Journal of Economics and Finance, 8(9), 234-248. http://dx.doi.org/10.5539/ijef.v8n9p234

Zeytoon, N. M. S. A. (2017, January). Industrial Design at the Service of Teaching Economics: 3D-Printed Prototypes and Materialized Demonstrations of Utility and Production Functions, A poster presented at the 2017 Allied Social Sciences Association (ASSA) Meeting in the American Economic Association (AEA) Economic Education Poster Session, Chicago, IL, USA.

Zeytoon, N. M. S. A., \& Naumenko, A. (2017, January). A Holistic Visual "Wheel of Relationships" in Production Theory, A poster presented at the 2017 Allied Social Sciences Association (ASSA) Meeting in the American Economic Association (AEA) Poster Session, Chicago, IL, USA.

\section{Copyrights}

Copyright for this article is retained by the author(s), with first publication rights granted to the journal.

This is an open-access article distributed under the terms and conditions of the Creative Commons Attribution license which permits unrestricted use, distribution, and reproduction in any medium, provided the original work is properly cited. 